\title{
AZ AMERIKAI MAGYAR RÓMAI ÉS GÖRÖG KATOLIKUS LELKIPÁSZTOROK RÉSZVÉTELE AZ AMERIKAI KÖZÉLETBEN ${ }^{1}$
}

\author{
DUDÁS RÓBERT GYULA
}

Ady Endre a 2o. század elején az Ülj törvényt, Werbőczi című költeményében így fogalmazott: „Úgy elfogy a magyar, / Mintha nem lett volna.” Ebben a költeményben - többek között - a századforduló azon különleges eseménysorának akart emléket állítani, amely a magyarságnak az Amerikai Egyesült Államokba s később Kanadába történő kivándorlását jelentette.

Adyt ez személyesen is érintette, hiszen egyik közeli barátja, Járdánházy Kovács Lajos $^{3}$ is a között a nagyjából kétmillió ${ }^{4}$ magyar állampolgárságú személy között volt, ${ }^{5}$ aki áthajózott az óceánon túlra. Adynak e barátja az egyike annak a - kutatásaim szerint ${ }^{6}$ - 1095 római, illetve görögkatolikus lelkipásztornak, akik életüket az amerikai magyarok szolgálatában élték le.? Ahhoz, hogy megvizsgál-

${ }^{1}$ A tanulmány megírásában Dr. Udvarvölgyi Zsolt történész, szociológus, az Apor Vilmos Katolikus Főiskola föiskolai tanára volt segítségemre.

2 Ady Endre: Ki látott engem? Budapest, Nyugat kiadó, 1914, in Ady Endre összes versei, Athenaeum kiadása, é. n. 329-378, 341.

${ }^{3}$ Kovács Lajos (Nagykanizsa, 1877 v. 1879. augusztus 31.-Detroit, MI, 1927. július 22.) plébános, újságíró.

${ }^{4}$ Kivándorlás Magyarországról Amerikába az első világháború előtti évtizedekben, https://lib.pte. hu/sites/ptebtkscan/mellekletek/2013_apr_kivandorlas/2013_14_kivandorlas_04.pdf （2019. március 11.)

${ }^{5}$ A kivándorlók nemzetiségi összetételével kapcsolatosan lásd: Szondi Ildikó, Seres Alíz Ivett: Tengerentúli magyarok, http://acta.bibl.u-szeged.hu/29294/1/juridpol_forum_001_002_169-200. pdf (2019. december 21.)

${ }^{6}$ A személyi adatok forrása: Dudás Róbert Gyula: Magyar katolikus papok Amerikában Az Amerikai Egyesült Államokban és Kanadában szolgálatot ellátott római és görögkatolikus magyar, magyar származású, valamint magyarul beszélő lelkipásztorok történeti névtára 1825-2018 között, sajtó alatt, 2020.

${ }^{7}$ Dudás Róbert Gyula: Magyar katolikus papi sorsok Észak-Amerikában. Adalékok az amerikai magyar katolikus pasztorációhoz, pályamü, XXXIV. Országos Tudományos Diákköri Konferencia, ELTE, Budapest, 2019, Humán Tudományi Szekció, Amerikai kultúra és történelem tagozati dolgozat, egyéni kutatás, sajtó alatt, 2020. 
juk az amerikai magyar papok feladatát a közéletben, két kérdést kell tisztáznunk. Az első, hogy miről (a közélet kérdése), a második, hogy kikről (amerikai magyar papok) lesz szó.

\section{KÖZÉLET FOGALMA}

A magyar nyelv értelmező szótára szerint a közélet „azon emberi tevékenységek és folyamatok összessége, amelyek az egész népközösség állami, politikai életével, elsősorban az állami vezető szervek és hatóságok munkájával, müködésével kapcsolatosak". ${ }^{8} \mathrm{Ez}$ a fogalommeghatározás a közélet kérdését - véleményem szerint - erősen leszűkíti, hiszen gyakorlatilag a politikát érti rajta. Jelen írásomban viszont a közéletet sokkal bővebb értelemben használom, hiszen az előbb idézett kéziszótár - néhány sorral később - a szó jelentését kiegészíti, miszerint a (közélet) „a közösség politikai, társadalmi élete, tevékenysége, életviszonyai”. ' Így ezt a fogalmat már egyértelműen és teljességben lehet alkalmazni a lelkipásztorok müködésére és tevékenységére is, mivel a papi szolgálat egyben közéleti tevékenységnek is tekinthetö.

\section{AZ AMERIKAI MAGYAR LELKIPÁSZTOROKRÓL}

Az első magyarok az 180o-as évek derekán jelentek meg az USA-ban, s az 1920-as években Kanadában. Ekkor már beszélhetünk egy bizonyos szintű missziós tevékenységről, nagyjából 20 római és görögkatolikus pap adatai ismertek, akik rövidebb-hosszabb ideig kint tartózkodtak. Ebben az időszakban viszont még nem beszélhetünk állandó magyar lelkipásztori jelenlétről, hanem egyrészt vagy nagyobb területeket láttak el a magyar papok, vagy pedig különböző amerikai egyházmegyék fogadták be az adott papot, s kapott saját plébániát, de a magyar pasztorációban nem vett részt. Az első amerikai püspök által kért, magyarországi püspök által felhatalmazással rendelkező görögkatolikus lelkipásztor (Dzubay Sándor ${ }^{10}$ ) 1888ban, az első római katolikus (Böhm Károly¹) pedig 1892-ben érkezett az USA-ba.

\footnotetext{
${ }^{8}$ A magyar nyelv értelmező szótára - Közélet, szerk. Bárczy Géza, Budapest, 1959-1962.

${ }^{9}$ Uo.

${ }^{10}$ Dzubay Sándor (Beregsárrét, 1857. február 12.-Trenton, NJ, 1933. április 2.) az első görögkatolikus magyar pap az USA-ban, átlépett az ortodox egyházba, ahol püspökké szentelték, később visszatért a katolikus egyházba.

${ }^{11}$ Böhm Károly (Selmecbánya, 1853. június 13.-Cleveland, OH, 1932. április 9.) az első hivatalosan kiérkezett római katolikus magyar pap, az „Amerikai magyarok apostola”.
} 
Az, hogy egy-egy adott pap a korábban említett közéleti szerepvállalást milyen módon éli meg, számos kérdéstől függött. Az első ilyen az adott személy habitusa, hozzáállása a saját maga személyiségéhez és papságához. Számos lelkipásztornál megfigyelhető volt olyan tevékenység, amely primer módon nem a papi szolgálatához kötődött. ${ }^{12}$ Ebben az írásban ezeket az „elfoglaltságokat” szeretném elsődlegesen megvizsgálni és bemutatni, ezzel is bizonyítva azt, hogy a Magyarországról származó római és görögkatolikus papok mennyi mindent hozzáadtak választott új országuk, valamint ezáltal az egész emberiség javához. Természetesen tisztában vagyok azzal, hogy egy ilyen rövid írás nem lehet minden szempontot kielégítően teljes, nem mutathat be minden szempontot. Jelen írásommal a magyar egyháztörténetnek ezeket a méltatlanul elfeledett papjait szeretném bemutatni, felkelteni rájuk a figyelmet, ezzel valamiféle kiindulópontot nyújtani a későbbi kutatások számára.

\section{AZ ELSÖ MAGYAR PAPOK}

Az 180o-as évek vége a magyar diaszpóra számára az önszerveződés, a demokrácia alapjainak felfedezése szempontjából igen termékeny. ${ }^{13}$ Ekkor alakultak ugyanis meg azok az egyesületek, egyletek, amelyek elöször csak a beteg, vagy elhunyt magyarokat (illetve azokat, akiknek az amerikai kaland annyira nem sikerült, hogy saját pénzből nem tudtak hazatérni) támogatta, majd - főleg Böhm Károly kiérkezése után - a templom és közösségépítések alapjává váltak. ${ }^{14}$

Két személyt szeretnénk megemlíteni, akik jelentősnek tekinthetőek ezen időszak nemzetiségi fejlődése szempontjából. Az első Böhm Károly, akit később az „amerikai magyarok apostolának" neveztek el. Az ö 1892-es kiérkezése tekinthető a szervezett magyar nyelvű római katolikus lelkipásztorkodás kezdetének. ${ }^{15} \mathrm{Böhm}$ és társai nem egy szokásos, átlagos környezetbe kerültek ki. Mindent önmaguknak kellett megoldaniuk, így feladatuk nem csak papi, hanem kifejezetten közéleti szerepvállalásnak tekinthető. Böhm Károly - a fennmaradt és az amerikai magyar katolikus szájhagyomány szerint, bár erre írásos bizonyítékot eddig nem találtam - kijelentette: először templomot kell építeni, lehetőleg nagy közösségi térrel, hogy a közösség találkozhasson. Utána iskolát kell alapítani, hogy a magyarság utánpótlása megmaradjon, illetve aki hazatér, annak gyermeke ne kerüljön hátrányos helyzetbe itthon. Majd újságot, hogy oda is eljusson a magyar szó, ahova esetleg ő

\footnotetext{
${ }^{12}$ Vö. Zulehner, Paul: Priester in Modernisierungsstress, Wien, 2001.

${ }^{13}$ Vö. Egyesületi élet Amerikában, http://www.bibl.u-szeged.hu/ha/emigracio/szovetsegek-hu. html (2019. október 9.)

${ }^{14}$ Vö. Kárpi Ferenc: Bőhm Károly pápai prelátus élet- és korrajza. 1885-1907. Cleveland, 1991.

${ }^{15}$ Uo.
} 
nem (számtalan missziós útja miatt ugyanis ilyen terület nem nagyon maradt), $s$ végül plébániát, ahol ő is élhet. Már egy ilyen feladat egész embert igényelt, nemhogy ennyi. Mégis az első lelkipásztorok ezt egészen jól megoldották, méghozzá úgy, hogy a közösséget minél jobban bevonták, feladatokat adtak ki, gyakorlatilag egy mai értelemben modernnek nevezhető plébániát alakítottak ki. ${ }^{16}$ Persze nem mondhatni, hogy mindenki megelégedésére, hiszen az ekkor már egyre terjedő szocialista mozgalmakkal számtalan vitájuk volt, szóban, írásban s néhanapján tettlegességben is ${ }^{17} \mathrm{~S}$ természetesen a hívekkel sem minden esetben kerültek egy „hullámhosszra”, ami miatt a kiérkező papok nagyjából 25\%-a rövid időn belül visszavándorolt az óhazába. Várlaky Sándor ${ }^{18} 1913$-ban a hívek - véleménye szerint - kissé eltúlzott szerepéről így fogalmazott: „Egy rendes és ennél fogva önérzetes pap kell, hogy igen hamar torkig legyen az amerikai miszterekkel, akik nem érezve hátuk mögött a szolgabíró nádpálcáját, minden durva brutalizmusnak szabad folyást engednek meg maguknak a fölszentelt papjaikkal szemben. Azok a gyülések, amelyekkel egyre zaklatják a papot, azok a kicsinyeskedések, az a sok buta szőrszálhasogatás, az a bántó bizalmatlankodás, amellyel a pap találkozik a hívek részéről, utálattal és csömörrel kell, hogy eltöltsék az embert."19

Az első kiérkező papok tevékenységének köszönhető, hogy - kutatásaim adatai szerint - már az 1920-as évekre majdnem 50 magyar templom, több mint 200 magyar egyesület, nagyjából 40 iskola és hasonló számú folyóirat jött létre.

Ha az első amerikai magyar papokról beszélünk, fontos megemlíteni a görögkatolikus atyákat is. Az első görögkatolikus pap Dzubay Sándor volt, aki 1888-ban érkezett meg az USA-ba, s nagyon nehéz helyzetben találta magát. A helyzetének megértéséhez szükséges, hogy megismerjük az Egyesült Államok hozzáállását a vallásokhoz. Hivatalosan az USA a „legvallásosabb vallástalan” ${ }^{20}$ ország, melynek Alkotmánya ${ }^{21}$ szerint az állam és a vallás teljesen szét van választva. Ez viszont főleg 19. század végén, a 20. század elején abban csúcsosodott ki, hogy a katolikus egyház elfogadottsága nagyon negatív volt. ${ }^{22}$ Számos protestáns döntéshozó

\footnotetext{
${ }^{16}$ Vö. Passaic: „A sz. István templom alapkőszentelése”, Religio 1903/9., 70.

${ }^{17}$ Vö. Nagy Dezső személyi anyaga, Kalocsai Főegyházmegyei Levéltár, Personaliák.

${ }^{18}$ Várlaky Sándor (Aranybánya, 1861. december 11.-Northampton, PA, 1933. október 2.) plébános.

${ }^{19}$ Máté Anita: Az amerikai magyar katolikusok és az Óhaza, Budapest, 2011, 35.

${ }^{20}$ Vallásosan müveletlenek az amerikaiak, https://mult-kor.hu/cikk.php?id=16752\&print=1 (2019. március 12.)

${ }^{21}$ Vö. Az Amerikai Egyesült Államok Alkotmánya VI. pont utolsó bekezdése, valamint az Alkotmány I. kiegészítése.

${ }^{22}$ A mai kor nagymértékű, jelentősen eltúlzott pedofil botrányai is ennek a negatív hozzáállásnak a következményei lehetnek, hiszen számarányában sokkal kisebb mértéküek ezek az esetek, mint más, gyermekekkel foglalkozó csoport esetén, mégis ez van leginkább kihangsúlyozva - a szerző megjegyzése.
} 
szerint a pápa bármikor beavatkozhatott volna az ország közéletébe, ${ }^{23}$ ezért a katolikusok sokáig elutasítottak, jobb esetben megtürtek voltak. A nemzetiségi nyelvü lelkipásztorkodás pedig különösen sokaknak szúrta a szemét, még az egyházon belül is. A bevándorló magyarok elsődlegesen olyan területeken telepedtek le, ahol az ír nemzetiség erős volt. ${ }^{24}$ Ezek katolikus püspökei pedig minden erővel arra törekedtek, hogy a hívek ne akarjanak saját nemzetiségi tömbben letelepedni, hanem vegyék át az amerikai stílust és nyelvet. ${ }^{25} \mathrm{Az}$ ír püspökök szemében különösen vörös posztó volt a görögkatolikusság. Erre példa, hogy a philadelphiai érsek külön imát végeztetett híveivel, hogy „az Isten ne engedje ennek a szektának az elterjedését itt Amerikában”. ${ }^{26} \mathrm{~A}$ helyzet tragikumát Tóth Elek példája jól bemutatja. Tóth Elek mint özvegy ment ki az USA-ba. A megérkezésének helyén illetékes püspök - bemutatkozás helyett - annyit kérdezett tőle, hogy maga nős? Erre Tóth Elek közölte, hogy özvegy. Erre az érsek válasza: Akkor maga nem pap. Ezt követően a munkácsi püspök megbízólevelét összetépte, s gyakorlatilag kidobatta a püspökségröl. Tóth atya hiába írt a munkácsi püspökségre, hiába írt Rómába, senki nem foglalkozott vele. Ekkor - úgy, mint az akkor kiérkező görögkatolikus atyáknak jelentős része - átlépett az ortodox egyházba. ${ }^{27}$ Kis túlzással úgy is fogalmazhatunk, hogy az amerikai ortodox egyház létrehozásánál a római katolikus püspökök bábáskodtak. Tevékenysége olyan szinten volt nagy hatású (zarándokhelyet alapított, nagy hatású beszédeket mondott, stb.), hogy az ortodox egyház néhány éve Wilkes-Berre-i Alexis ${ }^{28}$ néven szentté avatta.

\section{POLITIZÁLÓ PAPOK}

Bár komoly, a mai napig tartó vita $\operatorname{van}^{29}$ a katolikus egyházon belül, hogy a lelkipásztorok részt vehetnek-e a (párt)politikai életben, de időről időre mégis előfor-

${ }^{23}$ Vö. Erdő Péter: Az Apostoli Szentszék diplomáciája és a nemzetközi konfliktusok, http://epa. oszk.hu/o130o/o1397/ooo18/pdf/EPA01397_magyar_sion_2015_2_169-177.pdf (2019. december 21.)

${ }^{24} \mathrm{Az}$ Amerikai Egyesült Államok északkeleti része.

${ }^{25}$ Vö. Puskás Julianna: Az Egyesült Államok bevándorlási politikája (1890-1990), http://epa.oszk. hu/ooooo/ooo36/ooo15/pdf/10.pdf (2019. augusztus 10.)

${ }^{26}$ Az amerikai görögkatolikus egyház rövid története. Az amerikai Magyar Népszava jubileumi dísz-albuma. 1889-1909. H. n. (USA) 1909, 139.

${ }^{27}$ Vö. Vigh Kálmán: „Az amerikai görögkatolikus püspökség első évei”, Világtörténet 1997. ősz-tél 45-46.

${ }^{28}$ St. Alexis Toth, https://oca.org/fs/st-alexis-toth. (2019. március 11.)

${ }^{29}$ Vö. Beer Miklós: Egy papnak a napi pártpolitika fölött kell maradnia, https://hvg.hu/itthon/20180115_beer_miklos_szeged_csanadi_egyhazmegye_kipredikalas (2019. március 8.) 
dult, igaz, az anyaországinál sokkal kisebb mértékben, hogy egy-egy lelkipásztor a közössége érdekében, bizonyos szintű politikai, vagy inkább fogalmazzunk úgy, hogy lobbitevékenységet folytatott. Ennek elsődleges oka a 20. század fordulóján, s attól kezdve egészen az 1980-as évekig a papsághoz való hozzáállásban keresendő. Bár a legtöbb közösségben volt egyesület, valamint a templomok mellett müködtek az egyházközségi képviselötestületek, egyháztanácsok, mégis, ha tárgyalni kellett, vagy egyeztetni valamelyik hatósággal, az esetek nagy részében - a mai napig müködő népegyházi modell alapján - a pap ment. ${ }^{30}$ Igaz, a magyarországi helyzettel szemben a több esetben kellett kikérni a hívek véleményét, ami nem minden esetben volt a papság ínyére.

Az amerikai magyarok számára nagy lelki megrázkódtatást jelentett Trianon, a II. világháború és 1956. Trianon után számos magyar veszítette el annak lehetőségét, hogy úgy térjen haza, mint magyar állampolgár, hiszen a terület elcsatolásával az állampolgársága is megszünt. ${ }^{31}$ Ennek igazságtalansága ellen küzdött Eördögh Elemér ${ }^{32}$, Toledo, $\mathrm{OH}$-i magyar plébános. A küzdelem leglátványosabb lépése a Buffalói Magyarok Nemzetgyülésének megszervezésében és a Magyarok Világszövetségében mutatott közreműködés, ${ }^{33}$ valamint „Justice for Hungary”" ${ }^{34}$ óceánrepülés volt, melynek előkészületeit, anyagi feltételeinek megteremtését végezte. Persze, ezzel egy időben folyamatosan nyilatkozott magyarországi, illetve amerikai újságoknak a békediktátum igazságtalanságáról. ${ }^{35}$ Ugyanő 1944-ben minden erejével küzdött az ellen, hogy Magyarország a II. világháborúban harcoló félként benn maradjon, ezért valamennyi kitüntetését visszaküldte, tiltakozásként. ${ }^{36} \mathrm{Mi}$ vel korábban a neve felmerült, hogy esetleg az Amerikában élő magyarok püspöke legyen, s ez a folyamat ebben az időszakban, illetve ezután megakadt, látható, hogy a saját esetleges karrierérdekeit is félrerakta azért, hogy szeretett szülőhazája kikerüljön a háborúból. Szavai süket fülekre találtak. Később pedig szervezett le-

${ }^{30}$ Vö. Tomka Ferenc: A misszió és evangelizáció, https://vigilia.hu/regihonlap/2007/2/tomka.htm (2019. október 25.)

${ }^{31}$ Ugróczky Mária: Megtalált magyar állampolgárok, http://acta.bibl.u-szeged.hu/45299/1/juridpol_078_550-576.pdf (2019. október 23.)

${ }^{32}$ Eördögh Elemér prelátus (Kassa, 1875. június 4.-Toledo, OH, 1955. április 6.)

${ }^{33}$ Dudás Róbert Gyula: „Az amerikai magyarok 1929-es nemzetgyülése, a New York állambeli Buffalóban, különös tekintettel az egyházak szerepvállalására”, Egyháztörténeti Szemle, sajtó alatt, 2020.

${ }^{34}$ Fiziker Róbert: A Justice for Hungary utolsó útja, http://mnl.gov.hu/mnl/ol/hirek/a_justice_ for_hungary_utolso_utja_o (2019. október 25.)

${ }^{35}$ Bácskay Payerle Béla: „Magyar szivárvány az égen”, Zászlónk 1931. szeptember 15. 1. szám, 3-8.

36 „Eördögh prelátus érdemrendjei”, Délamerikai Magyarság 1944/2229. szám, 2. 
járató hadjárat indult ellene, mind a magyar, mind pedig az amerikai - baloldali - magyar sajtóban. ${ }^{37}$

1945 után az esetleges korábbi politikai szerepvállalás számos esetben az emigrálás legfőbb okaként mutatkozik..$^{38}$ Németh Kálmán Gellért ${ }^{39}$ atyát távollétében ítélték halálra, mivel az itthoni állapotokról információkat adott az amerikai illetékeseknek. Szintén halál várt volna itthon Végvári Vazul ${ }^{40}$ ferences szerzetesre, akit 1956-os tevékenysége miatt ítéltek el. Ö mint a Magyar Szabadságharcos Világszövetség elnöke is szolgált USA-ba való érkezése után. 1959. november 4-én az Egyesült Nemzetek szovjet delegációjának épületében felajánlotta, hogy hajlandó magyarországi bíróság elé állni 1956-os tevékenységéért, ha a hasonló vádak alapján kivégzésre váró magyar fiatalkorúakat a kommunista hatóságok szabadon engedik, és a Nemzetközi Vöröskeresztnek átadják. „Felajánlását” nem fogadták el, később 1997-es hazatelepüléséig számos helyen lelkipásztorkodott, valamint az Amerikai Katolikus Püspöki Kar Bevándorlási Bizottságának tanácsadójaként próbált segíteni - többek között - a magyar lelkipásztorokon. ${ }^{41}$

A II. világháború végének, illetve az azt követő rövid demokratikus átmenetnek jellegzetes személyisége volt Varga Béla ${ }^{42}$ veszprémi egyházmegyés áldozópap, balatonberényi plébános, aki az ideiglenes nemzetgyülés tagja, valamint az első kvázi szabadon választott Nemzetgyülés elnöke volt. Miután 1946-ban külföldre kényszerült, ${ }^{43} \mathrm{az}$ USA-ban telepedett le, $\mathrm{s}$ New Yorkban fejtett ki folyamatos politikai tevékenységet, a Magyar Nemzeti Bizottmány elnökeként tevékenykedett. Megvizsgálva munkásságát az látható, hogy ő azon papok közé tartozott, akik amerikai tartózkodásuk alatt egyáltalán nem vettek részt a szervezett magyar lelkipásztorkodásban, hanem kizárólag a politikai életben mozogtak. Ennek fő oka az volt, hogy véleménye szerint ez idő alatt az államföi feladatokat látta el, mivel az 1946. évi köztársaság létesítéséről szóló első törvény 15. cikkelye értelmében mint

${ }^{37}$ „Eckhardt és Chorin Ferenc pezsgős dáridója Newyorkban Habsburg Ottó tiszteletére”, Szabadság 1947. április-június (3. évfolyam, 74-145. szám) 1947. június 13. 131. szám

${ }^{38}$ Az 1945-1950 között emigráló, már felszentelt papok több mint felénél mutatható ki korábbi általában helyi szintü - politikai szerepvállalás.

${ }^{39}$ Németh Kálmán Gellért (Szamosújvár, 1897. január 27.-Brownsville, NY, 1966. március 26.) ferences, majd székelyudvarhelyi egyházmegyés áldozópap, író, 1945 után - emigrálása után, távollétében - halálra ítélték hazaárulás vádjával.

${ }^{40}$ Végvári László Vazul OFM (Székesfehérvár, 1929. szeptember 2.-Esztergom, 2011. szeptember 13.) ferences szerzetes, tanár.

${ }^{41}$ „Elhunyt Végvári Vazul ferences szerzetes”, Magyar Kurir, http://www.magyarkurir.hu/hirek/ elhunyt-vegvari-vazul-ferences-szerzetes/ (2019. szeptember 11.).

${ }^{42}$ Varga Béla (Börcs, 1903. február 18.-Budapest, 1995. október 13.) az Ideiglenes Nemzetgyülés tagja, az 1946-os Nemzetgyülés elnöke, a Magyar Nemzeti Bizottmány elnöke.

${ }^{43}$ Kovács K. Zoltán: „A Demokrata Néppárt belépése a magyar közéletbe”, Katolikus Szemle 40., Róma, 1988, 59-72. 
a parlament elnöke volt köteles az akadályoztatott köztársasági elnök helyett az államföi funkciókat ellátni. Varga Béla élete szép ívet mutat, miszerint 1990. május 2-án, az első szabadon választott Országgyűlés megnyitóülésén - a történelmi folytonosság okán - felszólalhatott, ${ }^{44}$ majd később Balatonberényben telepedett le, s ott is temették el.

\section{ÚJSÁGÍRÓ PAPOK}

Böhm Károly egyik alapelve volt, hogy a közösségnek újságot kell a kezébe adni. Az Egyesült Államok eleve nem engedett be olyan személyeket a területére, akik teljesen írástudatlanok voltak, így a kereslet a magyar nyelvü újságokra elég nagy volt. Feysz A. Hugolin ${ }^{45}$ ferences rendi szerzetes „Az amerikai magyar sajtó mérlege" ${ }^{16}$ címü értekezésében 1926-ban nagyjából 60 magyar nyelvü kiadványt gyüjtött össze. Véleménye szerint ezek egyike sem a klasszikus értelemben vett politikai vagy pedig társadalmi lap. Ennek fö oka az volt, hogy a magyarok olyan szinten szétszórva élnek, hogy egységes politikai fellépésről nem lehet szó, ha beszélnek is ezek az újságok a politikáról, akkor elsődlegesen a hazai politikai kérdéseket veszik sorra, úgy, mint királypárti, illetve köztársaságpárti újságok. Ezek mellett természetesen megjelennek - véleménye szerint - demagóg bolsevista újságok is. Természetesen nagyon jelentős szerepet töltöttek be a katolikus újságok, melyek hitbuzgalmi lapoknak voltak tekinthetők. Az egyik - a kortársak szerint - legjelentősebb ilyen újság - amely bárki számára az interneten elérhetö47 - a Hajnal címü kiadvány volt, melyet Messerschmiedt Geysa ${ }^{48}$ Passaic, NJ-i plébános adott ki 1908-1909 között. A benne szereplö írások ma már stílusuk miatt kissé furcsának tűnnek, de a kor katolikus szellemének tökéletesen megfeleltek. Különösen érdekes színfoltja az amerikai magyar újságírásnak Mogyorósi (Hermann) Árkád $\mathrm{OFM}^{49}$, aki az Önállás címü lapjában teljes egészében elutasította a Kazinczy-féle nyelvújítást és kizárólag a régi magyar nyelvet volt hajlandó használni.

${ }^{44}$ Varga Béla felszólalása, 1990. május 5. Magyar Országgyülés Honlapja, http://www.parlament. hu/naplo34/001/o010004.htm (2019. március 11.).

${ }^{45}$ Feysz A. Hugolin (Csáktornya, 1885. május 20.-Milwaukee, WI, 1944. március 3.) ferences.

${ }^{46}$ Feysz A. Hugolin: „Az amerikai magyar sajtó mérlege”, Katolikus Szemle 40. (1926) 3. szám 129-139.

${ }^{47}$ Hajnal, Szent István Római Katolikus Magyar Templom, Passaic, NJ. http://www.ststephenspassaic.com/history/thajnal.htm (2019. március 11.)

${ }^{48}$ Messerschmiedt Geysa (Bodrog, Somogy vármegye, 1870. július 4. v. Kassa, 1871. július 19.-Toledo, $\mathrm{OH}, 1912$. március 29.) plébános, újságíró.

${ }^{49}$ Mogyorósi (Hermann) Árkád (Mogyorós, 1851. február 6.-New York, NY, 1935. június 17.) ferences szerzetes, görög-latin szakos tanár, később - laikusként - a Rockefeller családnál nevelő. 
Egy egész évszázadot ölel fel gyakorlatilag a legjelentősebb magyar katolikus hetilap, a Katolikus Magyarok Vasárnapja, melynek szerkesztője majdnem húsz éven keresztül volt Dengl Miklós $\mathrm{OFM}^{50}$. Ezt az újságot Böhm Károly alapította 1894-ben, Magyarországi Szent Erzsébet Amerikai Hírnöke címmel, majd 1945-től a ferencesek vették át a szerkesztését. Dengl Miklós erdélyi származású ferences 1971-1988 között volt a lap föszerkesztője. Amellett, hogy a Katolikus Magyarok Vasárnapja ${ }^{51}$ a diaszpóra legjelentősebb magyar újságja lett, ez már nemcsak vallási jellegü cikkeket közölt, hanem az emigráció „hangjaként” felszólalt a magyarságot érintő jelentősebb politikai eseményekkel kapcsolatosan is. Ilyen volt többek között a határozott kiállás Mindszenty József bíboros mellett, ${ }^{52}$ valamint az ebben az időben lezajlódó polémia a Magyar Szent Korona visszaadása ügyében. ${ }^{53}$

Magát az újságot a ferences rend központi utasítására szüntették meg 1993-ban, melyet a diaszpóra magyarsága a mai napig nehezen fogad el.54

\section{TUDÓS, TANÁR PAPOK}

1950 körül a magyar oktatásban, így a középiskolai, majd ezzel egy időben a felsőoktatási intézményekben jelentős és drámai átrendeződés zajlott le, mivel a szerzetesrendektől, valamint az egyházi intézményektől elvették az oktatási lehetőséget. Számos szerzetesrend vezetése ezért úgy döntött, hogy a rendtartomány túlélése érdekében - föként a fiatal -szerzeteseit külföldre menekíti. Elsődleges célpont az USA, illetve Kanada lett. Az 1945-ös változások után kisebb mértékben, de 1956 után nagy számban érkeztek olyan atyák, akik már Magyarországon is föleg a tanításban vették ki részüket. Vizsgálva a neveket jelentős egyetemek katedráin szolgáló papokra találhatunk. Jáki Szaniszló OSB $^{55}$ a Princeton, Gábriel Asztrik

${ }^{50}$ Dengl Miklós OFM (Újarad, 1916. március 7.-Youngstown, OH, 1998. október 2.) plébános, újságíró.

${ }^{51}$ Katolikus Magyarok Vasárnapja, Magyar Katolikus Lexikon. http://lexikon.katolikus.hu/K/Katolikus\%2oMagyarok\%2oVas\%C3\%A1rnapja.html (2019. március 11.)

${ }^{52}$ Dudás Róbert Gyula: Mindszenty József 1974-es felmentésére adott reakciók a magyar diaszpórából, sajtó alatt, 2020.

${ }^{53}$ Dudás Róbert Gyula: A koronázási jelképek 1978-as visszaadásának kérdései az amerikai magyar sajtóban, Egyháztörténeti Szemle 2019/1. 138-145.

${ }^{54}$ Kiss G. Barnabás OFM, az újság utolsó szerkesztőjének szóbeli közlése.

${ }^{55}$ Jáki Szaniszló OSB (Győr, 1924. augusztus 17.-Madrid, Spanyolország, 2009. április 7.) Templeton-díjas tudománytörténész, tudományfilozófus, bencés szerzetes. 
Opraem $^{56}$, valamint Henkey-Hőnig Károly ${ }^{57}$ a Notre Dame oktatója, illetve Nagy Anzelm OCist ${ }^{58}$ apát, aki a Dallasi Egyetem matematika tanszékének volt tanára.

Különösen nagy számban érkeztek 1945 és 1956 után az USA-ba és Kanadába a jezsuiták (elsődlegesen Kanadában, illetve New Yorkban telepedtek le), a ciszterciek (Dallas, TX és Irving, TX) ${ }^{59}$, a bencések (Portola Valley, CA) ${ }^{60}$, a premontreiek (Orange, CA $)^{61}$, valamint a piaristák (Buffalo, NY, Washington DC) ${ }^{62}$. Ezek a rendek - szemben a ferencesekkel, akik szintén nagy számban érkeztek ki - kevésbé vették ki részüket a magyar pasztorációból, elsődlegesen iskolákat alapítottak, valamint az egyetemi oktatásban vettek részt. Az oktatásban tevékenykedő magyar papokat vizsgálva a bőség zavarával küzdünk. Volt közöttük olyan személy, akinek hatása akkora volt, hogy még a magyarországi - szabadnak legkevésbé sem mondható - egyháznak is „el kellett” ismernie érdemeit, hiszen Gábriel Asztrik OPraem, 1982-ben esztergomi egyházmegyei címzetes préposti kitüntetést kapott - ami rendkívül ritkának mondható az emigráns magyarság körében.

Jelen korunk jeles irodalmi személyiségének is nevezhető Farkasfalvy Dénes ${ }^{63}$ ciszterci apátot, aki - tanítási feladatai mellett - kiváló zsoltárfordításokat és számos egyéb irodalmi müvet adott a magyarságnak.

\section{SEGÉLYEKET SZERVEZŐ PAPOK}

Az amerikai magyar papokról nyugodtan elmondható, hogy nem voltak érzéketlenek az óhaza nehézségei iránt. Az első világháború után Marczinkó József ${ }^{64}$ akciót indított az itthon maradottak megsegítésére. Ennek módja az volt, hogy az Ameri-

${ }^{56}$ Gábriel Asztrik Opraem (Pécs, 1907. december 10.-Notre Dame, IN, 2005. május 16.) premontrei szerzetes, tanszékvezető egyetemi tanár.

${ }^{57}$ Henkey-Hőnig Károly (Miskolc, 1908. október 18.-Hamilton, ON, Kanada, 1999. július 30.) író, újságíró, lelkipásztor.

${ }^{58}$ Nagy Anzelm OCist (Buják, 1915. február 1.-Dallas, TX, 1988. augusztus 4.) dallasi apát, tanár.

${ }^{59}$ Farkasfalvy, Dénes: „Cistercians in Texas: The First Forty Years $\bigotimes$, in Thomas Pruit (szerk.), Cistercians in Texas. The 1998 Jubilee, Dallas, 1998, www.cistercian.org (2019. október 25.).

${ }^{60}$ Jávor, Egon: Beginnings: The Founding of Woodside Priory, Woodside Priory School, 2007; uő: Being Benedictine: 50 years of Woodside Priory School, Woodside Priory School, 2008, www. prioryca.org (2019. október 25.).

${ }^{61}$ Stack, Gabriel: A History of St. Michel's, tesi di laurea all'Università di Perpperdine, Malibu (California) 1997, www.stmichaelsabbey.com (2019. október 25.).

${ }^{62}$ Burgués, José: The Piarist Fathers in the U.S.A. 60 Years of Service. Escolapios en Estados Unidos [senza casa editrice], Miami, 2007-2008.

${ }^{63}$ Farkasfalvy Dénes OCist (Székesfehérvár, 1936. június 23.-) dallasi kiérdemesült apát.

${ }^{64}$ Marczikó József (Sátoraljaújhely, 1878. december 24.-Toledo, OH, 1935. június 28.) plébános, feltaláló. 
kában élő családok egy-egy csomagot küldhettek (elvileg díjmentesen) itthon élő $s$ rászoruló rokonaik részére. Az akció nagyságát jellemzi, hogy csak 1923. március 2-ig 11751 csomag érkezett meg Budapestre. ${ }^{65}$ Érdekesség kedvéért említhetjük meg, hogy természetesen ez is, mint minden program, okozott vitákat, például a parlament 1924. márciusi ülésén Bajcsy-Zsilinszky Endre Marczinkót, illetve a szétosztás módját interpellációban támadta, amely ellen ő erős hangvételü üzenetben tiltakozott. ${ }^{66}$

A második világháború alatti vészidőszakban a családi ágon ír származású Raile Jakab SJ ${ }^{67}$ komoly embermentő tevékenységet végzett. Amerikában töltött évei után hazarendelték, és a jezsuita tartomány fötitkára lett Budapesten 1935-tól 1942-ig. A II. világháború alatt a budapesti Pápai Nunciatúra Segítő Bizottságának elnökeként jezsuita rendtársait és családtagjait beszervezve, sok üldözöttnek nyújtott segítséget, amiért 1992. február 24-én posztumusz Yad Vashem díjat kapott Jeruzsálemben. A II. világháború, valamint 1956 után, Gáspár János ${ }^{68}$ passaici plébános, az Amerikai Magyar Liga alelnökeként szervezte és irányította a ruhaküldést Magyarországra, majd 1956 után is szervezte a segélyakciókat, ${ }^{69}$ valamint a kivándorlást az USA-ba. Gáspár János és Raile Jakab élete több ponton is találkozik. Mind a ketten szolgáltak Passaic, NJ-ben. Raile Jakab Gáspár János utasa volt abban a gépkocsiban, amely Newark, $\mathrm{NJ}$ mellett súlyos balesetet szenvedett, $\mathrm{s}$ ahol Raile Jakab elhunyt.

\section{FELTALÁLÓ PAPOK}

Két olyan magyar lelkészről van tudomásunk, aki olyan szabadalmat jelentett be amerikai tartózkodása alatt, mely a mai napig érvényesen fennáll. Érdekesség, hogy mind a kettő a szabadidős tevékenység megkönnyítéséhez kapcsolódik. A korábban már említett Marczinkó József 1928-ban United States Patent 1681590 számon saját szabadalmat nyújtott be, Bowling game board (Bowling játéktábla) néven..$^{\circ}$

${ }^{65}$ A szeretetadományok között a dunaparti teherpályaudvaron, Magyarország 1923. március 2. 49. szám, 2.

${ }^{66}$ „Bizonyításra szólítja föl Zsilinszky képviselőt a megvádolt Marczinkó plébános”, Pesti Hirlap 1924. március 28. 73. szám, 5 .

${ }^{67}$ Raile Jakab SJ (Vaskút. 1894. október 6.-Newark, NJ mellett, 1949. szeptember 6.) plébános, tanár, a Világ Igaza.

${ }^{68}$ Gáspár János (Magyarlak [Nagysároslak], 1898. május 6.-Passaic, NJ, 1963. február 25.) plébános, az Amerikai Magyar Liga alelnöke.

${ }^{69}$ Vö. Kerkayné Maczky Emese: 1956. november 4 után Passaicon. Passaic. NJ, USA, 2006.

${ }^{70}$ Vas László - Kerkayné Maczky Emese- Dudás Róbert Gyula: A passaici Szent István római katolikus magyar templom története, Domaszék, 2015, 12. 
A másik feljegyzett találmány sokkal inkább elterjedt, és a maga módján sokkal inkább hatással van emberek millióinak hétköznapjaira. Unger Lajos ${ }^{71} 1926-b a n$ jelentett be szabadalmat a mai napig használatban lévő cigarettapapír összetételére. Tanulmányában komoly gyakorlati érzékkel, különféle anyagok összekeverésével hozott létre, a leírása szerint élvezhető minőségű cigarettapapírt. Szabadalmának azonosítója: USoo1605085. ${ }^{72}$

\section{BEFEJEZÖ GONDOLATOK}

Nagyon szűk válogatást tudtunk csak bemutatni ezen a néhány oldalon, hiszen jelenlegi tudásunk szerint több mint ezer magyar, magyar származású, illetve magyarul beszélő katolikus pap vett részt az amerikai magyar pasztorációban. Az ő életük, mind papi, mind közéleti szerepük, jel a számunkra, hogy a magyarság szolgálata, $s$ a magyarokon keresztül Isten országának keresése, s az Örömhír továbbadása mindannyiunk feladata, akár alkalmasak vagyunk rá, akár nem. A kiérkező papok nem akartak hősök lenni. Ök csak a legjobb tudásuk szerint akartak szolgálni. S reméljük, megkapják, megkapták ezért a Mennyek Urának szerető ölelését.

${ }^{71}$ Unger Lajos (Peresznye, 1887. augusztus 25.-?, 1950 körül).

${ }^{72}$ Google Patents. https://patents.google.com/patent/US1605085A/en?inventor=Unger+Louis (2019. március 11.) 